\title{
Fifty years of Radiochimica Acta: a brief overview
}

\author{
By S. M. Qaim* \\ Research Centre Jülich and University of Cologne, Germany \\ (Received September 20, 2011; accepted in updated form February 13, 2012) \\ (Published online August 13, 2012)
}

\author{
Radiochimica Acta / Development history / \\ Editors, advisors, contributors and referees / \\ Impact factor and cited half-life / Top contributors / \\ Highly cited papers / International periodical
}

\begin{abstract}
Summary. This paper provides a brief account of the development of this journal over the last fifty years. Having started in 1962 as a modest outlet for reporting research results in radiochemistry, Radiochimica Acta soon became a respected specialist journal. There has been long-term continuity both in editorial activity and publishing management, resulting in welldefined publishing policies. Starting with the Founding Editors, the Board of Editors was changed only in 1977 and 1996. Similarly the original Publisher, Akademischer Verlag, published the journal until 1983. Since then Oldenbourg Wissenschaftsverlag has been managing the publication process. The journal has been broad-based, encompassing all chemical aspects of nuclear science and technology. It has played a significant role in the dissemination of new knowledge, occasionally by bringing forth special issues in fast emerging areas. It has kept pace with the changing trends in worldwide radiochemical research. Whereas by about the middle of 1980s all areas of radiochemistry were equally represented, today the emphasis is more on applied topics, such as chemical behaviour and mobility of actinides and fission products, accelerator-based radiochemistry, medical applications of radioactivity, etc. The number of published scientific contributions to date amounts to about 5100 , covering about 30000 printed pages. The total number of authors is around 7000. The journal follows a strict peer-review system and is supported by a network of about 400 referees. About 200 manuscripts are received per year, out of which $30-35 \%$ are rejected. The impact factor (IF) of the journal is almost the highest among the radiochemistry related journals, and the cited half-life (CHL) among the highest of all chemistry and physics oriented journals. In short, today Radiochimica Acta is a well established, internationally recognised periodical. Presently, approximately 50 percent of the published contributions originate from Europe, 25 percent from North- and South America and the remaining 25 percent from Asia, Australia and Africa together. All articles are published in English, and the journal is available to readership both on-line and in printed form.
\end{abstract}

\section{Introduction}

The journal Radiochimica Acta was founded in 1962, under the patronage of the Nobel Laureate Otto Hahn, to cater

\footnotetext{
*E-mail: s.m.qaim@fz-juelich.de.

(Co-ordinating Editor of the Journal)
}

for the publishing needs of the then fast expanding field of radiochemistry. In those days the radiochemists published their work in several different journals of chemistry and physics and had thus no platform of their own for technical communications. With the introduction of Radiochimica Acta a new era dawned for radiochemistry. Although published in Germany, right from its inception the journal aimed at inculcating an international character and flavour. In its very first issue, contributions were published from München, Karlsruhe, Köln, Jülich (Germany), Orsay (France), Amsterdam (The Netherlands), Yale (USA), Buenos Aires (Argentina) and Tokai (Japan).

The international character has been maintained, continuously nurtured and further developed over its life of 50 years. Manuscripts could be written in the early phase of the journal in any of the three international languages, viz. English, French and German; however, over the years the trend has completely shifted, so that today all the articles are published in the English language. Presently, approximately 50 percent of the published contributions originate from Europe, 25 percent from North- and South America and the remaining 25 percent from Asia, Australia and Africa together. This article prodvides a short overview of the development of the journal.

\section{Early phase}

The journal had a modest start and aimed at publishing four issues per year, constituting a volume of about 200 printed pages. Both full papers and short communications were accepted. The founding Editors and the Publisher, Akademische Verlagsgesellschaft in Wiesbaden (Germany), showed great dedication, perseverance and flexibility. The publication process was slow and took about a year, because the peer-reviewing was rather time consuming, the diagrams were often redrawn and printing technology was not very modern. Nonetheless, within four years of its existence, the journal size increased to two volumes per year, encompassing many branches of radiochemistry and covering about 450 pages.

Soon after the start of Radiochimica Acta, competition also set in, and a few other journals dealing with some specific aspects of radiochemistry and radioactivity came into existence. However, Radiochimica Acta continued to follow its path of serious scientific publishing with full deter- 
mination. It maintained its high standard, though the publishing speed was not improved; in fact to some extent it deteriorated.

\section{Enhanced progress and present status}

A big change came in 1977 when the whole Editorial Board was reconstituted and the scope of the journal was expanded to cover all "Chemical Aspects of Nuclear Science and Technology". It was decided to accept mostly full length papers after strict peer-reviewing. A concerted action was implemented to bring forth a series of special issues dealing with various important areas of radiochemistry (for a list see below). The published reviews were received very well; they considerably increased the stature of the journal. Furthermore, the review and publication processes were streamlined and the journal started appearing regularly and according to a preplanned schedule.

A further positive change came in 1983 when a new Publisher, "R. Oldenbourg Wissenschaftsverlag" in München (Germany), took over the publishing responsibility for Radiochimica Acta. It is still enthusiastically publishing the journal. Compared with international enterprises it is a small publishing house, but very serious and well embedded in the German tradition of quality printing. It has had the privilege and distinction of printing school books in Bavaria for over a hundred years and, in addition, publishing a few other research journals. Based on mutual trust and respect between the Editors and the Publisher, a spirit of long-term cooperation and joint venture developed. The journal size increased further. From 1991 onwards, it encompassed four volumes, each of about 200 pages.

In 1996 the Editorial Board changed again. The continuity in thought and purpose was, however, maintained and the spirit of corporate identity between the scientists and the Publisher continues to exist to date. The referee system became stricter and the publishing process started shifting to electronic system. From the year 2000 onwards, the four yearly volumes were merged to one volume of about 800 pages per year, with an issue appearing every month. This change in publishing schedule established the journal as a regular periodical. After acceptance, manuscripts are now handled completely electronically. As far as the number of published volumes is concerned, it is a very pleasant coincidence that this Golden Jubilee Year of the journal carries the volume number 100 .

\section{Editors and advisors}

The six founding editors of the journal (see Table 1) were assisted by about 25 advisors from all around the world. They did the hard ground work for setting the journal on a firm footing. Unfortunately, R. Wolfgang, the young and dynamic American Editor, died in 1971 and, with his death, the journal suffered a severe setback. The repercussions of his untimely demise were felt for many years.

In 1977 a new Editorial Board was constituted ( $c f$. Table 1). Originally it consisted of five members but soon another member joined the Board. A group of 6 radiochemists acted as advisors but the number was increased later to about 10 . This team continued till 1995, the coordinators being G. L. Stöcklin (1977-1982), K. H. Lieser (1982-1989) and J.-P. Adloff (1989-1995). During this period the journal attained an international standard, thanks to the hard and dedicated work by all concerned.

A restructuring of the Editorial Board occurred again in the beginning of 1996 ( $c f$. Table 1). With some replacements in between, today the Board consists of six editors, with S. M. Qaim as the Co-ordinating Editor. The untimely death of the active French Editor, C. Madic, in 2008 was a big loss and it took some time to recover from it. The Board is presently supported by 13 Advisors, representing the international radiochemistry community. A list of all persons who served as advisors to date is given in Table 2 .

Appreciation needs to be expressed to all the editors and advisors for their painstaking efforts to bring the journal to the scientific standing it enjoys today.

\section{Scope of the journal}

The scope of Radiochimica Acta has always been broadbased, encompassing all areas of fundamental and applied radiochemistry, including radiation chemistry. Of particular interest are topics like fundamental chemistry of actinides and transactinides, chemistry of nuclear energy production, nuclear reactions and nuclear data for applications, chemical consequences of nuclear transformations, radioanalytical techniques, environmental and speciation investigations, radiochemical separations and applications of radionuclides in all fields, especially in medicine (i.e. radiopharmaceutical chemistry). Over the years, as mentioned above, a few other journals dealing with specific topics such as radioanalytical chemistry, environmental radioactivity and radionuclide applications (especially in medicine and biology) have been established, but Radiochimica Acta has maintained its broad-based character.

The journal has played a significant role in dissemination of new knowledge in all areas of radiochemistry. Furthermore, it has always endeavoured to popularise newer knowledge by publishing authoritative review articles on topics of timely interest. In fast emerging areas it has periodically brought forth special issues to apprise the general readership of newer developments. Examples of special issues are:

- Chemical Aspects of the Nuclear Fuel Cycle (1978).

- Special Topics in Hot Atom Chemistry (1981).

- Radiochemistry Related to Life Science (Part I: 1982; Part II: 1983).

- Chemistry of Actinides and other Radioelements (1983).

- Chemistry of the Nuclear Fuel Cycle (1984).

- Radionuclides in the Chernobyl Accident (1987).

- A History and Analysis of the Discovery of Elements 104 and 105 (1987).

- Hot Atom Chemistry (1988).

- Inorganic and General Astatine Chemistry (1989).

- Behaviour and Utilization of Technetium (1993).

- Nuclear Data for Medical Applications (2001).

- Chemical Speciation (2005; 2009).

- Radiolanthanides in Therapy (2007).

- European Program for Partitioning of Minor Actinides (EUROPART, 2008). 
Table 1. Editors of Radiochimica Acta (in chronological order).

\begin{tabular}{|c|c|c|}
\hline $\begin{array}{l}\text { Serial } \\
\text { number }\end{array}$ & Name, place and country & $\begin{array}{l}\text { Period of } \\
\text { assignment }\end{array}$ \\
\hline \multicolumn{3}{|c|}{ Founding Editors } \\
\hline 1 & Strassmann, F., Mainz, Germany & $1962-1977$ \\
\hline 2 & Born, H.-J., München, Germany & $1962-1977$ \\
\hline 3 & Aten Jr., A. H. W., Amsterdam, The Netherlands & $1962-1977$ \\
\hline 4 & Regnaut, P., Fontenay-aux-Roses, France & $1962-1977$ \\
\hline 5 & Glueckauf, E., Harwell, United Kingdom & 1962-1977 \\
\hline 6 & Wolfgang, R., New Haven, USA & 1962-1971 (deceased) \\
\hline \multicolumn{3}{|c|}{ Interim Assignment } \\
\hline 7 & Friedlander, G., Brookhaven, USA & $1972-1973$ \\
\hline \multicolumn{3}{|c|}{ Second Phase Editors } \\
\hline 8 & Stöcklin, G. L., Jülich/Köln, Germany & $1977-1995$ \\
\hline 9 & Lieser, K.-H., Darmstadt, Germany & $1977-1995$ \\
\hline 10 & Adloff, J.-P., Strasbourg, France & $1977-1995$ \\
\hline 11 & Wolf, A. P., Brookhaven, USA & $1977-1995$ \\
\hline 12 & Wymer, R. G., Oak Ridge, USA & $1977-1989$ \\
\hline 13 & Pruett, D. J., Knoxville/Salt Lake City, USA & $1989-2000$ \\
\hline 14 & Tominaga, T., Tokyo, Japan & 1979-1995 \\
\hline \multicolumn{3}{|c|}{ Third Phase Editors } \\
\hline 15 & $\begin{array}{l}\text { Qaim, S. M., Jülich/Köln, Germany } \\
\text { (Co-ordinating Editor) }\end{array}$ & 1996-to date \\
\hline 16 & Kratz, J. V., Mainz, Germany & 1996-to date \\
\hline 17 & Gäggeler, H. W., Bern/Villigen, Switzerland & 1996-2003 \\
\hline 18 & Kudo, H., Sendai, Japan & 1997-2005 \\
\hline 19 & Shinohara, A., Osaka, Japan & 2005-to date \\
\hline 20 & Madic, C., Gif-sur-Yvette, France & 2001-2008 (deceased) \\
\hline 21 & Simoni, E., Orsay, France & 2008-to date \\
\hline 22 & Baisden, P. A., Livermore, USA & 1997-2003 \\
\hline 23 & Nitsche, H., Berkeley, USA & 2005-to date \\
\hline 24 & Nash, K. L., Pullman, USA & 2002-2009 \\
\hline 25 & Clark, S., Pullman, USA & 2010-to date \\
\hline
\end{tabular}

- Heavy Elements (Celebrating International Year of Chemistry, 2011).

- Innovative Positron Emitters (2011).

- Application of Radiotracers (2012).

A very special issue of the journal entitled: "One Hundred Years after the Discovery of Radioactivity”, covering 412 pages, was published in 1995. It contains authoritative reviews on almost all aspects of radiochemistry and has been hailed as a high class book. Even today, after 17 years, many of the articles are widely cited.

The journal has also published selected papers from some important conferences held in various regions of the world as special issues. The selection procedure has always been rigorous and the resulting standard of those publications was very high. Examples are Proceedings of the Migration Conferences published biennially (1988, 1990, 1992, 1994, 1996, 1998, 2000, 2002, 2004, 2006, 2008 and 2010), Proceedings of the Nuclear and Radiochemistry Conferences (NRC), held every four years, were published (1997, 2001, 2005) and Proceedings of the Plutonium Futures Conference held in Germany (2009). Selected papers from a few smaller but important workshops have also been published and are listed above as special issues. Thus the journal endeavours to report on the latest knowledge and developments in the field of radiochemistry on a global basis, maintaining its standard of peer-review process.

\section{Changing trends in radiochemical research}

As mentioned above, the scope of the journal has been very broad and manuscripts in all areas of radiochemistry could be published. However, with the passage of time, certain trends in published contributions started emerging. For example, in the 1960s and early 1970s more research was conducted on fundamental themes, such as nuclear reactions, chemical effects of nuclear transformations, studies on chemical equilibria using radiotracers, etc. In the late 1970 s, the emphasis started shifting to more applied problems like reactor technology, medical applications and environmentally related radioanalysis. By about the middle of 1980s work in all these areas was well established. An analysis shows that of all the published contributions in the years 1984 and 1985, about $25 \%$ were related to each of the four topics, namely, fundamental nuclear chemistry, chemistry of recoiling atoms, radiochemical separations and tracer studies, and chemistry of actinides and transactinides. Then came a very big shift in the philosophy and strategy of radiochemistry. With the reactor accident in Chernobyl in 1986, combined with the worldwide debate on the radioactive waste management, concerted 
Table 2. Advisors to the Editorial Board of Radiochimica Acta (in alphabetical order).

\begin{tabular}{|c|c|c|}
\hline $\begin{array}{l}\text { Serial } \\
\text { number }\end{array}$ & Name, place and country & $\begin{array}{c}\text { Period of } \\
\text { assignment }\end{array}$ \\
\hline 1 & Baumgärtner, F. München, Germany & $1962-2002$ \\
\hline 2 & Benes, P., Prague, Czech Republic & $1997-2008$ \\
\hline 3 & Boyd, G. E., Oak Ridge, USA & $1964-1976$ \\
\hline 4 & Cellini, R. F., Madrid, Spain & 1966-1976 \\
\hline 5 & Chai Z., Beijing, China & 2008-to date \\
\hline 6 & Clark, S., Pullman, USA & 2009-2009 \\
\hline 7 & Fisher, Ch., Gif-sur-Yvette, France & $1962-1976$ \\
\hline 8 & Flegenheimer, D. J., Buenos Aires, Argentina & $1962-1976$ \\
\hline 9 & Friedman, A., Argonne, USA & 1964-1976 \\
\hline 10 & Geckeis, H., Karlsruhe, Germany & 2008-to date \\
\hline 11 & Götte, H., Frankfurt, Germany & 1962-1976 \\
\hline 12 & Harbottle, G., Brookhaven, USA & $1962-1976$ \\
\hline 13 & Hecht, F., Vienna, Austria & $1962-1976$ \\
\hline 14 & Hernegger, F., Vienna, Austria & $1962-1976$ \\
\hline 15 & Herrmann, G., Mainz, Germany & $1962-1995$ \\
\hline 16 & Herr, W., Köln, Germany & $1962-1991$ \\
\hline 17 & Hyde, E. K., Berkeley, USA & 1962-1976 \\
\hline 18 & John, J., Prague, Czech Republic & 2009-to date \\
\hline 19 & Jurisson, S., Missouri, USA & 2010-to date \\
\hline 20 & Kalmykov, S. N., Moscow, Russia & 2009-to date \\
\hline 21 & Kim, J. I., Karlsruhe, Germany & 1996-2009 \\
\hline 22 & Kimura K., Tokyo, Japan & $1962-1976$ \\
\hline 23 & Kutschera, W., Vienna, Austria & $1996-2009$ \\
\hline 24 & Lieser, K. H., Darmstadt, Germany & $1962-1976$ \\
\hline 25 & Lindner, R., Braunschweig/Karlsruhe, Germany & $1962-1976$ \\
\hline 26 & Liu, Y., Beijing, China & 1989-2008 \\
\hline 27 & Maddock, A. G., Cambridge, United Kingdom & $1977-1996$ \\
\hline 28 & Madic, C., Fontenay-aux-Roses, France & $1996-2001$ \\
\hline 29 & Manchanda, V. K., Mumbai, India & 2004-to date \\
\hline 30 & Marcus, Y., Jerusalem, Israel & $1966-1976$ \\
\hline 31 & Meinke, W. W., Ann Arbor/Washington, USA & $1964-1976$ \\
\hline 32 & Merz, E., Jülich, Germany & $1962-1976$ \\
\hline 33 & Münzel, H., Karlsruhe, Germany & 1962-1976 \\
\hline 34 & Nagame, Y., Ibaraki, Japan & 2005-to date \\
\hline 35 & Nakahara, H., Tokyo, Japan & 1996-2005 \\
\hline 36 & Nakanishi, T., Kanazawa, Japan & $2005-2010$ \\
\hline 37 & Navratil, J. D., Golden, USA & $1983-1991$ \\
\hline 38 & Nitsche, H., Dresden, Germany; Berkeley, USA & $1996-2006$ \\
\hline 39 & Pappas, A. C., Oslo, Norway & 1962-1976 \\
\hline 40 & Parry, S., London, United Kingdom & 2007-to date \\
\hline 41 & Peterson, J. P., Knoxville, USA & 1997-2009 \\
\hline 42 & Qaim, S. M., Jülich, Germany & $1990-1995$ \\
\hline 43 & Ramaniah, M. V., Bombay, India & $1965-1976$ \\
\hline 44 & Riehl, N., München, Germany & $1962-1976$ \\
\hline 45 & Rösch, F., Mainz, Germany & 2010-to date \\
\hline 46 & Roth, E., Saclay, France & $1979-1991$ \\
\hline 47 & Ruth, T. J., Vancouver, Canada & 1999-to date \\
\hline 48 & Saito, N., Tokyo, Japan & $1968-1996$ \\
\hline 49 & Seelmann-Eggebert, W., Karlsruhe, Germany & $1962-1976$ \\
\hline 50 & Shinohara, A., Osaka, Japan & $2002-2005$ \\
\hline 51 & Shiokawa, T., Sendai, Japan & $1977-1991$ \\
\hline 52 & Simoni, E., Orsay, France & $2002-2008$ \\
\hline 53 & Smales, A. A., Harwell, United Kingdom & $1964-1976$ \\
\hline 54 & Starke, K., Marburg, Germany & $1962-1976$ \\
\hline 55 & Türler, A., München, Germany; Bern, Switzerland & 2003-to date \\
\hline 56 & Vargas, J. V., Belo Horizonte, Brazil & $1962-1976$ \\
\hline 57 & Warwick, P., Loughborough, United Kingdom & 1994-to date \\
\hline 58 & Yoshihara, K., Sendai, Japan & $1992-2001$ \\
\hline 59 & Zaidi, J. H., Islamabad, Pakistan & 2007-to date \\
\hline 60 & Zifferero, M., Rome, Italy & $1962-1976$ \\
\hline 61 & Zvára, I., Moscow, Russia & 1981-2009 \\
\hline
\end{tabular}

actions were initiated to understand the chemical behaviour and mobility of actinides and fission products under various natural conditions (i.e. migration). Those investigations are of fundamental significance, for example, in developing safe deep geological repositories for nuclear waste, and are very urgent. The other, rather longer-term strategy, involved separation of long-lived fission waste and its destruction by nuclear incineration (partitioning and transmutation). Both types of studies have continued for more than 20 years and are still expanding. The intensified and changing research ac- 
tivities are reflected in the type of publications seen in Radiochimica Acta.

Another area which has attracted tremendous attention over the last 25 years is related to accelerator-based radiochemistry. Here two directions are conspicuous. First, studies of superheavy elements. Though the work is carried out only in a few specialized laboratories, the number of associated scientists from several other institutions is large. The results obtained are very exciting, with the Periodic Table extended by physical methods up to $Z=118$ and by chemical methods up to $Z=114$, and newer information is pouring in. The second direction is the development of short-lived positron emitting radionuclides and attaching them to organic molecules. These latter studies have led to tremendous progress in Positron Emission Tomography (PET), a non-invasive organ imaging technique for in vivo study of metabolic processes. Thus, in addition to inorganic and coordination-chemistry based tracers for Single Photon Emission Tomography (SPECT), e.g. with ${ }^{99 \mathrm{~m}} \mathrm{Tc}$, a special type of organic radiochemistry has emerged which combines some significant features of both fundamental nuclear chemistry and hot atom chemistry. Needless to say that PET, SPECT and endoradiotherapy studies cannot be performed without radiochemistry. Worth pointing out also is that both the areas of accelerator-based radiochemistry are extremely interdisciplinary: the superheavy element research overlaps heavily with physics, and the radiopharmaceutical chemistry with medicine. The results are therefore dispersed in several journals, but Radiochimica Acta receives a considerable share of contributions in both the fields.

A statistical analysis of the papers published in recent years in Radiochimica Acta shows that about $50 \%$ of the contributions deal with the chemistry of the actinides and fission products, about $30 \%$ with non-energy related themes (like radionuclide production, radiopharmaceutical development, radiochemical separations, radioanalysis etc.) and the remaining $20 \%$ with fundamental nuclear, radio- and radiation chemistry. A newer emerging area is radioactivity combined with nanotechnology, but so far the number of contributions published in this journal has been very small.

\section{Contributors to the journal}

Over the last 50 years radiochemists from all corners of the globe have communicated their research results to Radiochimica Acta. About 5100 articles, covering about 30000 printed pages, have been published. The number of contributing authors amounts to about 7000 . About 4000 of all the authors contributed just one article, 1300 two articles, 500 three articles, 300 four articles, and about 200 five articles. About 175 scientists contributed more than 10 papers each. The top contributors to the journal are listed in Table 3. The Editors and the Publisher express their gratitude to all authors for their life-time dedication to the journal and to the field of radiochemistry.

\section{Referees and review process}

The standard of a primary journal is mainly dependent on the peer-review process which is followed after the submission of a manuscript. Radiochimica Acta has continually tried to maintain a hard but fair review system. To this endeavour it has built up a network of about 400 experts in various branches of radiochemistry who act as referees when requested. A very grateful acknowledgement is due to our referees who do excellent work on an honorary basis. A note of appreciation is published every few years, but it is realized fully that the referees' efforts are not to be compensated. The referees and the editors have generally a sympathetic approach to the authors and try to help them with regard to the improvement of their manuscripts, both technically and linguistically. The journal receives about 200 manuscripts per year, out of which less than $5 \%$ are immediately acceptable. Most of the manuscripts have to be revised, some of them several times. The rejection rate is $30-35 \%$. Our endeavour is to complete the review process within about four months but it depends on several factors, such as delay with the referee, workload on the editor etc., but often the author does not respond to the criticism as fast as is desirable. The Publisher adheres to the policy that an accepted normal manuscript should appear in print within about five months.

\section{Impact of the journal}

The importance of a scientific journal is judged today by various criteria. Needless to say that good editing, correct language, clean setting and printing, rapid appearance in print (first on-line, later paper version) and regularity in time-schedule are still very important factors. However, the citation of a paper in the literature is becoming a more important criterion. Here two aspects appear to be very relevant: firstly, the impact factor (IF), which shows how much interest an article has aroused within the considered time-period, and secondly, the cited half-life (CHL) which depicts the importance of the article over a longer period. These two aspects are discussed below with respect to radiochemistry related journals.

\subsection{Impact factor}

The impact factors of the four radiochemistry-related journals, namely, J. Radioanalytical and Nuclear Chemistry (JRNC), J. Labelled Compounds and Radiopharmaceuticals (JLCR), Applied Radiation and Isotopes (ARI), and Radiochimica Acta (RCA), are plotted in Fig. 1 for the period 1995-2010. Evidently the values are not high for all the periodicals. This reflects the size of the community which is not very large. Another conspicuous characteristic is that the value fluctuates considerably from one year to the next. This is particularly so for JLCR. In general, except for JRNC, which has a consistently lower impact factor, the values for the other three journals are more or less around 1.1. For Radiochimica Acta, over the last several years, the impact factor has been increasing and became the highest, reaching a value of about 1.5 in 2009. J. Environmental Radioactivity has some features common to radiochemistry journals, but not all. Its impact factor is close to that of Radiochimica Acta. 
Table 3. Top contributors to Radiochimica Acta (list ${ }^{a}$ of authors with more than 25 lifetime contributions).

\begin{tabular}{ll}
\hline Rank $\quad$ Author and affiliation & $\begin{array}{c}\text { Number of } \\
\text { contributions }\end{array}$
\end{tabular}

\begin{tabular}{|c|c|c|}
\hline 1 & $\begin{array}{l}\text { Syed M. Qaim } \\
\text { Forschungszentrum Jülich and Universität zu Köln, Germany }\end{array}$ & 96 \\
\hline 2 & $\begin{array}{l}\text { Jae-Il Kim } \\
\text { Technische Universität München and Forschungszentrum Karlsruhe, Germany }\end{array}$ & 93 \\
\hline 3 & $\begin{array}{l}\text { Gregory R. Choppin } \\
\text { Florida State University, Tallahassee, Florida, USA }\end{array}$ & 81 \\
\hline 4 & $\begin{array}{l}\text { Karl H. Lieser }{ }^{\dagger} \\
\text { Technische Hochschule Darmstadt, Germany }\end{array}$ & 78 \\
\hline 5 & $\begin{array}{l}\text { Heino Nitsche } \\
\text { Lawrence Berkeley National Laboratory, Berkeley, California, USA }\end{array}$ & 56 \\
\hline 6 & $\begin{array}{l}\text { Norbert Trautmann } \\
\text { Universität Mainz, Germany }\end{array}$ & 52 \\
\hline 7 & $\begin{array}{l}\text { Jens V. Kratz } \\
\text { Universität Mainz, Germany }\end{array}$ & 52 \\
\hline 8 & $\begin{array}{l}\text { Thomas Fanghänel } \\
\text { Forschungszentrum Karlsruhe and EC Joint Research Centre, Karlsruhe, Germany }\end{array}$ & 51 \\
\hline 9 & $\begin{array}{l}\text { Günter Herrmann } \\
\text { Universität Mainz, Germany }\end{array}$ & 42 \\
\hline 10 & $\begin{array}{l}\text { Kenji Yoshihara } \\
\text { Tohoku University, Sendai, Japan }\end{array}$ & 42 \\
\hline 11 & $\begin{array}{l}\text { Frank Rösch } \\
\text { Universität Mainz, Germany }\end{array}$ & 41 \\
\hline 12 & $\begin{array}{l}\text { Gert Bernhard } \\
\text { Forschungszentrum Dresden-Rossendorf, Germany }\end{array}$ & 40 \\
\hline 13 & $\begin{array}{l}\text { Vijay K. Manchanda } \\
\text { Bhabha Atomic Research Centre, Trombay, India }\end{array}$ & 40 \\
\hline 14 & $\begin{array}{l}\text { Bernd Eichler } \\
\text { Joint Institute of Nuclear Research, Dubna, USSR, and University of Bern, Switzerland }\end{array}$ & 38 \\
\hline 15 & $\begin{array}{l}\text { Mathias Schädel } \\
\text { Gesellschaft für Schwerionenforschung, Darmstadt, Germany }\end{array}$ & 37 \\
\hline 16 & $\begin{array}{l}\text { Andreas Türler } \\
\text { Paul-Scherrer-Institut, Villigen, Switzerland }\end{array}$ & 35 \\
\hline 17 & $\begin{array}{l}\text { W. Brüchle } \\
\text { Gesellschaft für Schwerionenforschung, Darmstadt, Germany }\end{array}$ & 33 \\
\hline 18 & $\begin{array}{l}\text { Heinz W. Gäggeler } \\
\text { Paul-Scherrer-Institut, Villigen, Switzerland }\end{array}$ & 33 \\
\hline 19 & $\begin{array}{l}\text { Jamshed H. Zaidi } \\
\text { Pakistan Institute of Nuclear Science and Technology, Islamabad, Pakistan }\end{array}$ & 32 \\
\hline 20 & $\begin{array}{l}\text { Darleane C. Hoffman } \\
\text { Lawrence Berkeley National Laboratory, Berkeley, California, USA }\end{array}$ & 32 \\
\hline 21 & $\begin{array}{l}\text { Volker Neck } \\
\text { Forschungszentrum Karlsruhe, Germany }\end{array}$ & 31 \\
\hline 22 & $\begin{array}{l}\text { Gerhard L. Stöcklin }{ }^{\dagger} \\
\text { Forschungszentrum Jülich, Germany }\end{array}$ & 30 \\
\hline 23 & $\begin{array}{l}\text { Helmut Münzel }^{\dagger} \\
\text { Forschungszentrum Karlsruhe and Technische Hochschule Darmstadt, Germany }\end{array}$ & 29 \\
\hline 24 & $\begin{array}{l}\text { A. H. W. Aten, Jr. }{ }^{\dagger} \\
\text { Institut voor Kernphysisch Onderzoek, Amsterdam, The Netherlands }\end{array}$ & 29 \\
\hline 25 & $\begin{array}{l}\text { Alfred P. Wolf }{ }^{\dagger} \\
\text { Brookhaven National Laboratory, Upton, New York, USA }\end{array}$ & 28 \\
\hline 26 & $\begin{array}{l}\text { Jean P. Adloff } \\
\text { Université Louis-Pasteur, Strasbourg, France }\end{array}$ & 28 \\
\hline 27 & $\begin{array}{l}\text { Prasanta K. Mohapatra } \\
\text { Bhabha Atomic Research Centre, Trombay, India }\end{array}$ & 28 \\
\hline 28 & $\begin{array}{l}\text { G. A. Brinkman }{ }^{\dagger} \\
\text { National Institute of Physics, Amsterdam, The Netherlands }\end{array}$ & 27 \\
\hline 29 & $\begin{array}{l}\text { Tsutomu Sekine } \\
\text { Tohoku University, Sendai, Japan }\end{array}$ & 27 \\
\hline 30 & $\begin{array}{l}\text { K. E. Gregorich } \\
\text { Lawrence Berkeley National Laboratory, Berkeley, California, USA }\end{array}$ & 27 \\
\hline 31 & $\begin{array}{l}\text { Robert Guillaumont } \\
\text { Institut de Physique Nucléaire, Université de Paris Sud, Orsay, France }\end{array}$ & 26 \\
\hline 32 & $\begin{array}{l}\text { Andrew R. Felmy } \\
\text { Pacific Northwest National Laboratory, Richland, Washington, USA }\end{array}$ & 26 \\
\hline
\end{tabular}

a: Printed and accepted contributions till 31 January 2012; information extracted from Web of Knowledge, Thomson Reuters, USA; independently corroborated by the staff of R. Oldenbourg Wissenschaftsverlag, München, Germany.

${ }^{\dagger}$ Deceased. 


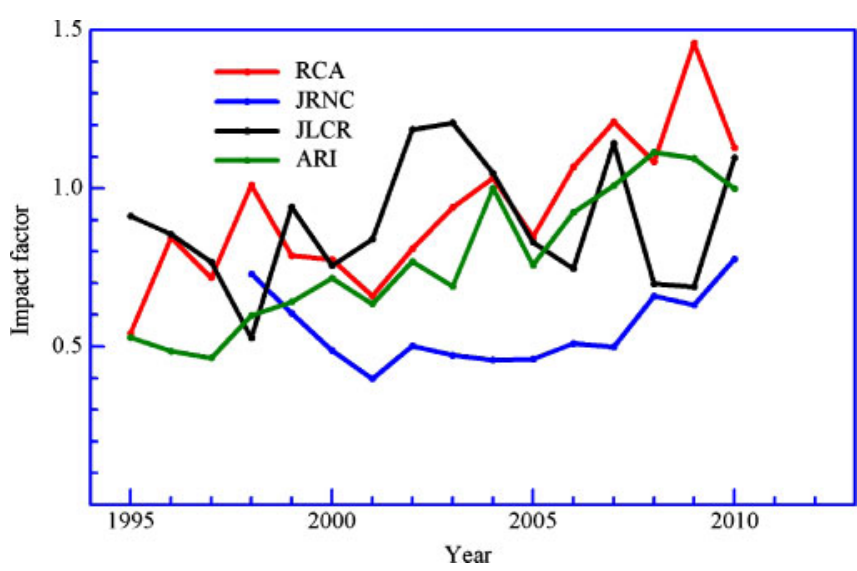

Fig. 1. Impact factor (IF) of radiochemistry-related journals over the period 1995 to 2010 (information extracted from "Journal Citation Reports", Thomson Reuters, USA).

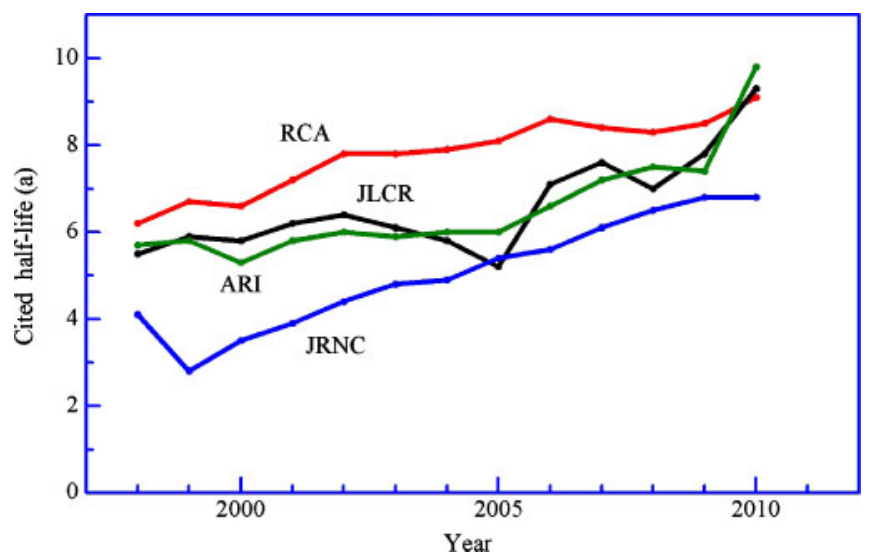

Fig. 2. Cited half-lives (CHL) of radiochemistry-related journals over the period 1998 to 2010 (information extracted from "Journal Citation Reports", Thomson Reuters, USA).

\subsection{Cited half-life}

The cited half-lives of the above mentioned four radiochemistry-related journals are given for the period 1998-2010 in Fig. 2. Evidently the values for Radiochimica Acta are among the highest. In fact the values for Radiochimica Acta are even higher than those for most of the broad-based chemistry and physics journals. These numbers depict that the papers published in Radiochimica Acta are of long-term value, with citations extending up to 25 years or even more.

\section{Highly cited publications}

The importance of an individual article is often judged by the number of citations it has received, though it is not necessarily always a positive index. A paper with controversial results, for example, may be highly criticized (and so highly cited). Nonetheless, looking positively at the matter, a highly cited paper adds prestige to a journal. The information available in the Web of Knowledge (Thomson Reuters, USA) showed that a large number of papers published in Radiochimica Acta received high citations. The publications with more than 50 citations are listed in Table 4. An analysis shows that most of them deal with the actinides, followed by papers on medically oriented radiochemistry, superheavy
Table 4. Highly cited Radiochimica Acta publications (papers with more than 50 citations).

\begin{tabular}{|c|c|c|}
\hline Rank & $\begin{array}{l}\text { Title of publication, authors } \\
\text { and reference }\end{array}$ & $\begin{array}{l}\text { Number of } \\
\text { citations }^{a}\end{array}$ \\
\hline 1 & $\begin{array}{l}\text { Actinide environmental chemistry } \\
\text { R. J. Silva, H. Nitsche } \\
\text { RCA 70/71, 377-396 (1995) }\end{array}$ & 181 \\
\hline 2 & $\begin{array}{l}\text { Solubility and hydrolysis of tetravalent actinides } \\
\text { V. Neck, J. I. Kim } \\
\text { RCA 89, 1-16 (2001) }\end{array}$ & 151 \\
\hline 3 & $\begin{array}{l}\text { Humics and radionuclide migration } \\
\text { G. R. Choppin } \\
\text { RCA 44/45, 23-28 (1988) }\end{array}$ & 143 \\
\hline 4 & $\begin{array}{l}\text { Solution chemistry of the actinides } \\
\text { G. R. Choppin } \\
\text { RCA 32, 43-53 (1983) }\end{array}$ & 140 \\
\hline 5 & $\begin{array}{l}\text { Absolute cross sections for the production } \\
\text { of }{ }^{18} \mathrm{~F} \text { via the }{ }^{18} \mathrm{O}(p, n)^{18} \mathrm{~F} \text { reaction } \\
\text { T. J. Ruth, A. P. Wolf } \\
\text { RCA 26, 21-24 (1979) }\end{array}$ & 129 \\
\hline 6 & $\begin{array}{l}\text { Europium(III) and americium(III) stability } \\
\text { constants with humic acid } \\
\text { R. A. Torres, G. R. Choppin } \\
\text { RCA 35, 143-148 (1984) }\end{array}$ & 123 \\
\hline 7 & $\begin{array}{l}\text { Speciation of uranium in seepage waters of } \\
\text { mine tailing pile studied by time-resolved laser- } \\
\text { induced fluorescence spectroscopy (TRLFS) } \\
\text { G. Bernhard, G. Geipel, V. Brendler, H. Nitsche } \\
\text { RCA 74, 87-91 (1996) }\end{array}$ & 120 \\
\hline 8 & $\begin{array}{l}\text { Uranyl(VI) carbonate complex formation: } \\
\text { validation of the } \mathrm{Ca}_{2} \mathrm{UO}_{2}\left(\mathrm{CO}_{3}\right)_{3} \text { (aq.) } \\
\text { species } \\
\text { G. Bernhard, G. Geipel, T. Reich, V. Brendler, } \\
\text { S. Amayri, H. Nitsche } \\
\text { RCA 89, 511-518 (2001) }\end{array}$ & 113 \\
\hline 9 & $\begin{array}{l}\text { Complexation of metal ions with humic acid: } \\
\text { metal ion charge neutralization model } \\
\text { J. I. Kim, K. R. Czerwinski } \\
\text { RCA 73, 5-10 (1996) }\end{array}$ & 109 \\
\hline 10 & $\begin{array}{l}\text { The role of natural organics in radionuclide } \\
\text { migration in natural aquifer systems } \\
\text { G. R. Choppin } \\
\text { RCA 58/59, 113-120 (1992) }\end{array}$ & 107 \\
\hline 11 & $\begin{array}{l}\text { Actinide colloid generation in groundwater } \\
\text { J. I. Kim } \\
\text { RCA 52/53, 71-81 (1991) }\end{array}$ & 94 \\
\hline 12 & $\begin{array}{l}\text { No-carrier-added radiohalogenation methods } \\
\text { with heavy halogens } \\
\text { H. H. Coenen, S. M. Moerlein, G. Stöcklin } \\
\text { RCA 34, 47-68 (1983) }\end{array}$ & 91 \\
\hline 13 & $\begin{array}{l}\text { Complexation of the uranyl ion with aquatic } \\
\text { humic acid } \\
\text { K. R. Czerwinski, G. Buckau, F. Scherbaum, } \\
\text { J. I. Kim } \\
\text { RCA 65, 111-119 (1994) }\end{array}$ & 86 \\
\hline
\end{tabular}


Table 4. (Continued).

\begin{tabular}{ll} 
Rank & $\begin{array}{l}\text { Title of publication, authors } \\
\text { and reference }\end{array}$ \\
\hline 14 & $\begin{array}{l}\text { The release of uranium, plutonium, cesium, } \\
\text { strontium, technetium and iodine from spent } \\
\text { fuel under unsaturated conditions }\end{array}$ \\
& P. A. Finn, J. C. Hoh, S. F. Wolf, S. A. Slater, \\
J. K. Bates \\
RCA 74, 65-71 (1996)
\end{tabular}

15 Actinide separation science

G. R. Choppin, K. L. Nash,

RCA 70/71, 225-236 (1995)

16 Complexation of pentavalent and hexavalent

actinides by fluoride

G. R. Choppin, L. F. Rao

RCA 37, 143-146 (1984)

17 Technetium in the hydrosphere and in the geosphere, 1 . Chemistry of technetium and iron in natural waters and influence of the redox potential on the sorption of technetium

K. H. Lieser, C. Bauscher

RCA 42, 205-213 (1987)

18 Chemical properties of element 105 in aqueous solution: halide complex-formation and anionexchange into triisoctyl amine

J. V. Kratz, H. P. Zimmermann, U. W. Scherer,

M. Schädel, W. Brüchle, K. E. Gregorich,

C. M. Ganett, H. L. Hall, R. A. Henderson,

D. M. Lee, J. D. Leyba, M. J. Nurmia,

D. C. Hoffman, H. Gäggeler, D. Jost, U. Baltens-

perger, Ya. Nai-Qi, A. Türler, Ch. Lienert

RCA 48, 121-133 (1989)

19 Occurrence of $\mathrm{Pu}$ and fissiogenic REE in

hydrothermal apatites from the fossil nuclear

Number of

citations $^{a}$

85

25
and fulvic acids

J. J. Lenhart, S. E. Cabaniss, P. MacCarthy,

B. D. Honeyman

RCA 88, 345-353 (2000)

26 Aqueous chemistry of element 105

67

K. E. Gregorich, R. A. Henderson, D. M. Lee,

M. J. Nurmia, R. M. Chasteler, H. L. Hall,

D. A. Bennett, C. M. Gannett, R. B. Chadwick,

J. D. Leyba, D. C. Hoffman, G. Herrmann RCA 43, 223-231 (1988)

27 Complexation of americium(III) with humic acid

67

J. I. Kim, G. Buckau, E. Bryant, R. Klenze

RCA 48, 135-143 (1989)

28 Uranium adsorption on ferrihydrite: effects

of phosphate and humic acid

T. E. Payne, J. A. Davis, T. D. Waite

RCA 74, 239-243 (1996)

29 ARCA-II: a new apparatus for fast, repetitive

HPLC separations

M. Schädel, W. Brüchle, E. Jäger, E. Schimpf,

J. V. Kratz, U. W. Scherer, H. P. Zimmermann RCA 48, 171-176 (1989)

30 A study of curium(III) humate complexation

by time-resolved laser-fluorescence spectroscopy

(TRLFS)

J. I. Kim, H. Wimmer, R. Klenze,

RCA 54, 35-41 (1991)

31 Neptunium redox speciation

M. R. Antonio, L. Soderholm, C. W. Williams,

J.-P. Blaudeau, B. E. Bursten

RCA 89, 17-25 (2001)

R. Bros, J. Carpena, V. Sere, A. Beltritti

RCA 74, 277-282 (1996)

20 Uranium(VI) sulphate complexation studied

by time-resolved laser-induced fluorescence

spectroscopy (TRLFS)

G. Geipel, A. Brachmann, V. Brendler,

G. Bernhard, H. Nitsche

RCA 75, 199-204 (1996)

32 Excitation functions of $(p, x n)$-reactions on ${ }^{\text {nat }} \mathrm{Ni}$ and highly enriched ${ }^{62} \mathrm{Ni}$ - possibility of

production of medically important radioisotope

${ }^{62} \mathrm{Cu}$ at a small cyclotron

H. Piel, S. M. Qaim, G. Stöcklin

RCA 57, 1-5 (1992)

33 Radionuclides in the geosphere: sources, mobility, reactions in natural waters and interactions with

T. Rabung, T. Stumpf, H. Geckeis, R. Klenze,

J. I. Kim

RCA 88, 711-716 (2000)

22 Separation of actinides in different oxidation

states by solvent-extraction

P. A. Bertrand, G. R. Choppin

RCA 31, 135-137 (1982)

23 The solubility of plutonium hydroxide in dilute

72

solution and in high-ionic-strength chloride brines

A. R. Felmy, D. Rai, M. J. Mason, R. W. Fulton

RCA 48, 29-35 (1989)

24 Speciation of aquatic actinide ions by pulsed laser

69 spectroscopy

R. Klenze, J. I. Kim, H. Wimmer

RCA 52/53, 97-103 (1991) solids

K. H. Lieser

RCA 70/71, 355-375 (1995)

A study of groundwater-colloids and their geochemical interactions with natural radionuclides in Gorleben

J. P. L. Dearlove, G. Longworth, M. Ivanovich, J. I. Kim, B. Delakowitz, P. Zeh RCA 52/53, 83-89 (1991)

35 Chemical interactions of actinide ions with 62 groundwater colloids in Gorleben aquifer systems J. I. Kim, P. Zeh, B. Delakowitz RCA 58/59, 147-154 (1992)

36 Solubility and hydrolysis behaviour of neptunium $(\mathrm{V})$

V. Neck, J. I. Kim, B. Kanellakopulos RCA 56, 25-30 (1992) 
Table 4. (Continued).

\begin{tabular}{ll} 
Rank & $\begin{array}{l}\text { Title of publication, authors } \\
\text { and reference }\end{array}$ \\
\hline $37 \quad \begin{array}{l}\text { Applicability of calixarene-crown compound for } \\
\text { the removal of cesium from alkaline tank waste }\end{array}$ \\
T. J. Haverlock, P. V. Bonnesen, R. A. Sachleben, \\
B. A. Moyer \\
RCA 76, 103-108 (1997)
\end{tabular}

38 Hydrolysis reactions of neptunium(V)

61 C. Lierse, W. Treiber, J. I. Kim RCA 38, 27-28 (1985)

39 Mixed $\mathrm{Ca}^{2+} / \mathrm{UO}_{2}{ }^{2+} \mathrm{CO}_{3}{ }^{2-}$ complex formation at different ionic strengths

S. N. Kalmykov, G. R. Choppin RCA 88, 603-606 (2000)

40 Structure of uranium sorption complexes at 60 montmorillonite edge sites C. Hennig, T. Reich, R. Dähn, A. M. Scheidegger RCA 90, 653-657 (2002)

41 Evaluation of enthalpy of adsorption

from thermochromatographic data

Number of citations $^{a}$

62

B. Eichler, I. Zvara

RCA 30, 233-238 (1982)

42 Complexation of trivalent actinide ions

$\left(\mathrm{Am}^{3+}, \mathrm{Cm}^{3+}\right)$ with humic acid: a comparison of different experimental methods

J. I. Kim, D. S. Rhee, H. Wimmer, G. Buckau,

R. Klenze

RCA 62, 35-43 (1993)

43 Colloids in groundwater and their influence 59 on migration of trace elements and radionuclides

K. H. Lieser, A. Ament, R. Hill, R. N. Singh,

U. Stingl, B. Thybusch

RCA 49, 83-100 (1990)

44 Determination of the hydration number of $\mathrm{Cm}$ (III)

in various aqueous solutions

T. Kimura, G. R. Choppin, Y. Kato, Z. Yoshida RCA 72, 61-64 (1996)

45 A study of the surface sorption process of 59 $\mathrm{Cm}$ (III) on silica by time-resolved laser fluorescence spectroscopy(I)

K. H. Chung, R. Klenze, K. K. Park,

P. Paviet-Hartmann, J. I. Kim

RCA 82, 215-219 (1998),

46 Influence of soil humic acid and fulvic acid on sorption of thorium(IV) on MX-80 bentonite

D. Xu, X. K. Wang, C. L. Chen, X. Zhou,

X. L. Tan

RCA 94, 429-434 (2006)

47 Reactions of nucleogenic halogen atoms in liquid halobenzenes (recoil halogenation-III)

K. Berei, G. Stöcklin

RCA 15, 39-46 (1971)

48 Effect of $\mathrm{pH}$ and fulvic acid on sorption and complexation of cobalt onto bare and FA bound MX-80 bentonite

D. Xu, D. D. Shao, C. L. Chen, A. P. Ren,

X. K. Wang

RCA 94, 97-102 (2006)
Table 4. (Continued).

Rank Title of publication, authors Number of and reference

citations $^{a}$

49 Reaktionen von ${ }^{38} \mathrm{Cl}$-Rückstossatomen in den $\quad 55$ binären Systemen $\mathrm{CCl}_{4}$-Benzol und $\mathrm{CCl}_{4}$-Toluol G. Stöcklin, W. Tornau RCA 6, 86-93 (1966)

50 Solubility products of plutonium(IV) oxide and $\quad 55$ hydroxide J. I. Kim, B. Kanellakopulos RCA 48, 145-150 (1989)

51 The determination of the first hydrolysis constant 55 of $\mathrm{Eu}(\mathrm{III})$ and $\mathrm{Am}(\mathrm{III})$

M. S. Caceci, G. R. Choppin RCA 33, 101-104 (1983)

52 The solubility of Th(IV) and U(IV) hydrous 55 oxides in concentrated $\mathrm{NaCl}$ and $\mathrm{MgCl}_{2}$ solutions D. Rai, A. R. Felmy, S. M. Sterner, D. A. Moore, M. J. Mason, C. F. Novak RCA 79, 239-247 (1997)

53 Technetium in the nuclear fuel cycle, in medicine and in the environment

K. H. Lieser

RCA 63, 5-8 (1993)

54 The solubility of hydrous thorium(IV) oxide in chloride media - development of an aqueous ion-interaction model

A. R. Felmy, D. Rai, M. J. Mason RCA 55, 177-185 (1991)

$55 \quad$ Nuclear data relevant to the production of the positron emitting radioisotope ${ }^{86} \mathrm{Y}$ via the ${ }^{86} \mathrm{Sr}(p, n)$ - and nat $\mathrm{Rb}\left({ }^{3} \mathrm{He}, x n\right)$-processes F. Rösch, S. M. Qaim, G. Stöcklin RCA 61, 1-8 (1993)

56 Production of some medically important shortlived neutron-deficient radioisotopes of halogens S. M. Qaim, G. Stöcklin RCA 34, 25-40 (1983)

57 Complexation of Am(III) with humic acids of different origin J. I. Kim, D. S. Rhee, G. Buckau RCA 52/53, 49-55 (1991)

$58 \quad$ Hydrolysis of actinyl(VI) cations

G. R. Choppin, J. N. Mathur RCA 52/53, 25-28 (1991),

59 Complexation of trivalent actinide ions $\left(\mathrm{Am}^{3+}, \mathrm{Cm}^{3+}\right)$ with humic acid: the effect of ionic strength

K. R. Czerwinski, J. I. Kim, D. S. Rhee, G. Buckau RCA 72, 179-187 (1996)

60 A comparison of natural human acids with synthetic umic acid model substances: characterization and nteraction with uranium(VI) S. Pompe, M. Bubner, M. A. Denecke, T. Reich, A. Brachmann, G. Geipel, R. Nicolai, K. H. Heise, H. Nitsche RCA 74, 135-140 (1996) 
Table 4. (Continued).

\begin{tabular}{llc}
\hline Rank & $\begin{array}{l}\text { Title of publication, authors } \\
\text { and reference }\end{array}$ & $\begin{array}{c}\text { Number of } \\
\text { citations }^{a}\end{array}$ \\
\hline 61 & $\begin{array}{l}\text { Neptunium incorporation into uranyl compounds } \\
\text { that form as alteration products of spent nuclear } \\
\text { fuel: Implications for geologic repository } \\
\text { performance }\end{array}$ & 53 \\
& $\begin{array}{l}\text { P. C. Burns, K. M. Deely, S. Skanthakumar } \\
\text { RCA 92, 151-159 (2004) }\end{array}$ \\
\hline 62 & $\begin{array}{l}\text { Reactions of nucleogenic chlorine atoms with } \\
\text { simple aromatic compounds: recoil chlorination II } \\
\text { G. Stöcklin, W. Tornau } \\
\text { RCA 9, 95-105 (1968) }\end{array}$ \\
\hline
\end{tabular}

63 A study of hydrolysis reaction of curium(III) by time-resolved laser-fluorescence spectroscopy H. Wimmer, R. Klenze, J. I. Kim RCA 56, 79-83 (1992)

64 A column experiment for the study of colloidal 52 radionuclide migration in Gorleben aquifer systems

J. I. Kim, B. Delakowitz, P. Zeh, D. Klotz,

D. Lazik

RCA 66/67, 165-171 (1994)

65 Solubility, hydrolysis and colloid formation of plutonium(IV)

R. Knopp, V. Neck, J. I. Kim

RCA 86, 101-108 (1999)

66 Plutonium isotopic composition in soil from the former Semipalatinsk nuclear test site M. Yamamoto, A. Tsumura, Y. Katayama, T. Tsukatani

RCA 72, 209-215 (1996)

67 Sorption of uranyl ions on hydrous silicon dioxide

K. H. Lieser, S. Quandtklenk, B. Thybusch RCA 57, 45-50 (1992)

68 The Rossendorf beam line ROBL - a dedicated 51 experimental station for XAFS measurements of actinides and other radionuclides

T. Reich, G. Bernhard, G. Geipel, H. Funke,

C. Hennig, A. Rossberg, W. Matz, N. Schnell,

H. Nitsche

RCA 88, 633-637 (2000)

a: Information extracted from Web of Knowledge, Thomson Reuters, USA (status 31 January 2012).

elements, environmental radiochemistry and hot atom chemistry. The Editors and the Publisher congratulate the authors on achieving this manifested distinction and have pleasure in thanking them for publishing excellent work in this journal.

\section{Patrons of the journal}

Many of the top contributors given in Table 3 have also been acting as editors, advisors or referees. Some of them are very distinguished scientists, carrying all types of national and international honours and awards. The journal had also the honour of getting attention of four Nobel Laureates in Chemistry. One of them, Otto Hahn, was the Found- ing Father of this journal. Two others, Glenn T. Seaborg and F. Sherwood Rowland, contributed several papers to the journal. The former was a beacon of light for nuclear and actinide chemists and the latter for hot atom chemists. The fourth one, Yuan T. Lee, performed molecular beam studies of hot atom chemical reactions. We have pleasure in reproducing excerpts from one article of each of them in the Historical Section of this issue. The Editors and the Publisher thank with respect and gratitude all the patrons of the journal for their moral support and encouragement provided over the last 50 years.

\section{Publishing staff}

After the acceptance of a manuscript by the Editor the responsibility is shifted to the Publisher whose staff then handles all stages of the publication process. In this connection it is important to mention the name of Marianne Lotze whose untiring efforts up to the age of 90 made Radiochimica Acta a journal of high printing precision. In more recent years, Kristin Berber-Nerlinger and Birgit Zoglmeier have been efficiently managing the printing process under the supervision of Angelika Sperlich. At the higher administrative level, for about 25 years Johannes Oldenbourg personally and over the last three years Christine Autenrieth have been paying great attention to the smooth publishing of Radiochimica Acta.

\section{Concluding remarks and future perspectives}

After a hard struggle over many years, Radiochimica Acta attained the stature of a well-established international periodical about 30 years ago. Since then it has been publishing comprehensive research reports which have a long-lasting impact. It is a broad-based journal, encompassing all areas of radiochemistry. All articles are published in English and the Editors take responsibility for ensuring a high linguistic standard as well. The peer-review process is strict but fair, the rejection rate amounting to $30-35 \%$. The Publisher endeavours to serve the scientific community efficiently and is keeping pace with the on-going fast development in the publishing technology. The future prospects for the journal thus appear to be bright, provided all patrons (contributors, referees, editors, advisors, etc.) continue to support the journal with the same zeal and fervour as in the past.

Acknowledgments. A close contact has existed between the journal Radiochimica Acta and several research institutes around the world, the home organisations of the Editors and Advisors. The association has been particularly strong with the Institute of Nuclear Chemistry of the University of Mainz (through F. Strassmann as Founding Editor (1962-1977), J. V. Kratz as Editor (1996 to date); G. Herrmann as long-time advisor (1962-1995)) and the Institute of Nuclear Chemistry of the Research Centre Jülich (through G. Stöcklin as Editor (1977-1995) and S. M. Qaim as Co-ordinating Editor (1996 to date)). Thanks are due to all concerned institutions for providing infrastructure support to the editorial work of the journal. On a personal note, the author feels indebted to many persons in the Institute of Nuclear Chemistry in Jülich for their continued help with regard to the editorial work, in particular H.H. Coenen for advice and moral support, B. Scholten and M. Holschbach for extracting journal-related information from Journal Citation Reports and Web of Knowledge (Thomson Reuters, USA), Gabriele Faulbrück for handling editorial correspondence, and I. Spahn and S. Spellerberg for general assistance. 